\title{
PAPILLARY CARCINOMA THYROID- RELATION TO LYMPHOCYTIC THYROIDITIS
}

\author{
Deepa Narayanan ${ }^{1}$, Sindhu Kattali Bhaskaran²
}

1Assistant Professor, Department of Transfusion Medicine, Government Medical College, Kozhikode, Kerala. 2Professor, Department of Pathology, Government Medical College, Kozhikode, Kerala.

\section{BACKGROUND}

\section{ABSTRACT}

Coexistence of papillary carcinoma and lymphocytic thyroiditis has been described in many studies. It is not known whether the lymphocytic thyroiditis is only an immune reaction or lymphocytic thyroiditis is a risk factor for papillary carcinoma.

Aims and Objectives:

1. To estimate the prevalence and severity of lymphocytic infiltration in thyroids resected for papillary carcinoma, follicular neoplasm and multinodular goitre.

2. To estimate the extent and severity of lymphocytic infiltration in areas adjacent to the tumour and the rest of the thyroid in cases of papillary carcinoma.

\section{MATERIALS AND METHODS}

This is a descriptive study. 52 cases of papillary carcinoma, 48 cases of follicular neoplasm and/ or 100 cases of multinodular goitre were studied. Formalin fixed paraffin embedded sections stained by haematoxylin and eosin are scanned for lymphocytic thyroiditis and grading for thyroiditis done.

\section{RESULTS}

Papillary carcinoma showed significant association with lymphocytic thyroiditis. Grade of lymphocytic thyroiditis was not higher just around the tumour compared to non-tumourous areas in thyroidectomy specimens resected for papillary carcinoma.

\section{CONCLUSION}

Papillary carcinoma shows association with lymphocytic thyroiditis. Lymphocytic thyroiditis of higher grade is also seen in nontumourous areas of thyroid with papillary carcinoma.

\section{KEYWORDS}

Papillary Carcinoma, Lymphocytic Thyroiditis, Follicular Neoplasm, Nodular Goitre.

HOW TO CITE THIS ARTICLE: Narayanan D, Bhaskaran SK. Papillary carcinoma thyroid- relation to lymphocytic thyroiditis. J. Evolution Med. Dent. Sci. 2018;7(15):1892-1897, DOI: 10.14260/jemds/2018/426

\section{BACKGROUND}

Association of lymphocytic thyroiditis and papillary carcinoma thyroid has been studied in different populations. The possibility of autoimmune thyroiditis as a predisposing factor for papillary carcinoma thyroid has been suggested.

It is not known whether lymphocytic thyroiditis is a risk factor for papillary carcinoma thyroid or is a reaction to the tumour. Some studies have found a favourable outcome for papillary carcinoma thyroid in the presence of lymphocytic thyroiditis. This being the support for the hypotheses that lymphocytic infiltration represents a form of immune reaction.

If thyroiditis is not tumour specific, it would be seen throughout the excised specimen and not immediately adjacent to tumour alone. In addition, if there is a casual link between papillary cancer and thyroiditis, such thyroids would have higher degree of lymphocytic infiltration when compared to those having follicular neoplasm and nodular colloid goitre. This is the idea behind the current study.

'Financial or Other Competing Interest': None.

Submission 13-12-2017, Peer Review 24-03-2018,

Acceptance 31-03-2018, Published 09-04-2018.

Corresponding Author:

Deepa Narayanan,

Assistant Professor

Department of Transfusion Medicine,

Government Medical College,

Kozhikode, Kerala.

E-mail: drdeepa2@gmail.com

DOI: $10.14260 /$ jemds $/ 2018 / 426$

(c) (i) $(-)$

\section{Lymphocytic Thyroiditis in Papillary Carcinoma}

The association between lymphocytic thyroiditis and papillary thyroid carcinoma (PTC) has been studied. The coexistence of these two diseases has been variously reported to range from $0.3-38 \% \%^{1,2,3}$ There is ethnic, geographic and gender differences in the prevalence of both diseases. ${ }^{1}$ The occurrence of lymphocytic thyroiditis along with papillary thyroid carcinoma has been reported with fewer recurrences and an improved survival. ${ }^{2}$ The aetiologic relationship between thyroid carcinoma and lymphocytic thyroiditis is a point of dispute. It is not clear whether thyroiditis is induced by neoplasm ${ }^{1}$ or that thyroiditis predisposes the patient to the development of thyroid carcinoma

Nonspecific lymphocytic infiltration is commonly recognised adjacent to a thyroid neoplasm. ${ }^{1}$ One may therefore postulate that thyroiditis associated with thyroid carcinoma, in most cases, is secondary to the neoplasm representing the reaction induced by an antigen from the neoplasm itself. The patients with lymphocytic thyroiditis had a lower TNM score at diagnosis. This is consistent with the hypothesis that lymphocytic response limits tumour growth and metastases. ${ }^{1}$ The infiltrated lymphocytes from patients with PTC are likely to be cytotoxic $\mathrm{T}$ cells with natural killer or lymphokine-associated killer activity acting as carcinoma cell killers. ${ }^{4}$

These anti-tumour lymphocytes may also secrete cytokines such as interleukin-1 that inhibit thyroid carcinoma growth. ${ }^{4}$ 
The improved prognosis has been reported in patients with more aggressive thyroid tumour types associated with the presence of lymphocytic thyroiditis by Segal et al. ${ }^{1}$ The limited diseases was noted in the group with lymphocytic thyroiditis, despite most patients having a more aggressive tumour type. The presence of lymphocytic thyroiditis may be considered as a form of immune reaction to control tumour growth and proliferation. Papillary carcinoma thyroid with lymphocytic thyroiditis is associated with good prognosis. ${ }^{2}$ In a review of 1533 patients with a long postoperative duration of follow-up, Kashima et $\mathrm{al}^{2}$ reported a $5 \%$ cancer-specific mortality and an $85 \%$ relapse-free 10 -yr survival rate in patients without lymphocytic thyroiditis compared with $0.7 \%$ mortality and $95 \%$ relapse-free 10-yr survival rate respectively in those with lymphocytic thyroiditis.

\section{Lymphocytic Thyroiditis in Multinodular Goitre}

Lymphocytic thyroiditis can occur along with multinodular goitre. Increased incidence of lymphocytic thyroiditis occurs when iodine is introduced into a endemic goitre region. 50 to 45 percent of women and 20 percent of men in the United Kingdom and the United States have some degree of focal thyroiditis at autopsy ( 1 to 10 foci per square centimetre). ${ }^{6}$

Thyroid FNA study in 764 goitrous girls in India was done in post iodisation phase, which showed juvenile autoimmune thyroiditis in $7.5 \%$ which included Hashimoto's thyroiditis in $5.6 \%$ and focal lymphocytic thyroiditis in $1.9 \% .{ }^{7}$ High level of iodine intake may cause goitre in children. ${ }^{8}$

The overall prevalence of serologically diagnosed autoimmune thyroiditis in 2801 schoolgirls surveyed by Jaksic et $\mathrm{al}^{6}$ was $0.6 \%$, whereas the goitre-specific prevalence was $12.4 \%$. In a study from Epirus, overall prevalence of JAT was $3.3 \%$ and the goitre-specific prevalence was $16.5 \%{ }^{9}$

Autoimmune thyroiditis manifests either as a goitrous or atrophic variant. Goitrous autoimmune thyroiditis could either present as focal or diffuse lymphocytic thyroiditis. The goitre in Hashimoto's may be asymmetric and in a euthyroid patient can be mistaken for a solitary nodule or multinodular goitre. Diffuse thyroiditis when associated with eosinophilic changes and follicular destruction is called Hashimoto's thyroiditis (HT). 10

Other cross-sectional studies from Europe, the United States and Japan also have similar findings. These findings are important in iodine-replete communities. ${ }^{11,12,13,14}$

Hashimoto's thyroiditis may present as multinodular goitre clinically. The thyroid enlargement in Hashimoto's thyroiditis may be firm and nodular. Hashimoto's thyroiditis with increasing age at presentation, the proportion of patients presenting with MNG or STN increases. ${ }^{15}$ This may be because fibrosis and nodule formation in autoimmune thyroiditis may take several years. ${ }^{16}$

\section{Objectives of this Study are-}

1. To estimate the prevalence and severity of lymphocytic infiltration in thyroids resected for papillary carcinoma, follicular neoplasm and multinodular goitre.

2. To estimate the extent and severity of lymphocytic infiltration in areas adjacent to the tumour and the rest of the thyroid in cases of papillary carcinoma.

\section{MATERIALS AND METHODS}

\section{Cases Included}

This is a descriptive study. Thyroidectomy specimens of papillary carcinoma, follicular neoplasms and multinodular goitre were included in the study. Follicular neoplasms included follicular carcinoma, follicular adenoma, Hurthle cell carcinoma and Hurthle cell adenoma. 52 cases of papillary carcinoma, 48 cases of follicular neoplasms and 100 cases of multinodular goitre were taken for the study. Ethical clearance was obtained.

Formalin fixed, paraffin embedded sections, stained by $\mathrm{H}$ and $\mathrm{E}$ were studied and grading for lymphocytic thyroiditis was done. Grading was done as below.

\section{Grading for Lymphocytic Thyroiditis}

- Grade I- 2 to 8 foci/ standard representative section.

- Grade II- 9 to 40 foci/ standard representative section.

- Grade III- > 40 foci/ standard representative section.

- Grade IV- > 50\% of glandular parenchyma replaced by lymphocytic thyroiditis or presence of Hashimoto's thyroiditis.

One focus is collection of more than 50 lymphocytes. Grading of lymphocytic thyroiditis is done in multinodular goitres, papillary carcinoma, follicular neoplasm and compared.

In cases of papillary carcinoma, grade of lymphocytic infiltrate within $2 \mathrm{~cm}$ of neoplasm and grade of lymphocytic infiltrate outside $2 \mathrm{~cm}$ of tumour is observed.

Total of 52 papillary carcinoma, 48 follicular neoplasms and 100 multinodular goitre were studied. In one papillary carcinoma whole of the gland was involved with tumour, so it was not taken for statistical analysis.

Statistical analysis using chi-square test is done to compare papillary carcinoma with follicular neoplasm and multinodular goitre.

\section{RESULTS}

$56 \%$ of papillary carcinoma, $44 \%$ of follicular neoplasm and $39 \%$ of nodular goitre were associated with lymphocytic thyroiditis. Chi-square square test showing a ' $p$ ' value of 0.1117 . Higher grade of lymphocytic thyroiditis (Grade 2 and above) was found in $41.2 \%$ of papillary carcinoma, $21 \%$ of nodular goitre and $29.2 \%$ of follicular neoplasm. Higher grade (Grade 2 and above) of lymphocytic thyroiditis showed significant association with papillary carcinoma with ' $p$ ' value of 0.03 .

All thyroid lesions are common in the age group of 20 to 50. Papillary carcinoma is the commonest cause, for which thyroidectomy is done below 20 yrs. After 70 yrs. thyroidectomies are usually done for neoplasm. No increase in cancer prevalence was found in this group as age increases. Out of the 52 cases of papillary carcinoma, only 10 were males. Out of 48 follicular neoplasms, only 9 cases were males.

In papillary carcinoma which showed lymphocytic thyroiditis, it was seen in the non-tumourous areas also. Higher Grade of lymphocytic thyroiditis was seen not just around the tumour, but also in non-tumourous areas in papillary carcinoma. 


\begin{tabular}{|c|c|c|c|}
\hline & MNG & $\begin{array}{c}\text { Papillary } \\
\text { Carcinoma }\end{array}$ & $\begin{array}{c}\text { Follicular } \\
\text { Neoplasms }\end{array}$ \\
\hline $10-19$ & & $2(4 \%)$ & \\
\hline $20-29$ & $22(22 \%)$ & $13(25 \%)$ & $12(25 \%)$ \\
\hline $30-39$ & $36(36 \%)$ & $14(27 \%)$ & $10(21 \%)$ \\
\hline $40-49$ & $23(23 \%)$ & $10(19 \%)$ & $12(25 \%)$ \\
\hline $50-59$ & $11(11 \%)$ & $6(12 \%)$ & $10(21 \%)$ \\
\hline $60-69$ & $8(8 \%)$ & $5(10 \%)$ & $2(4 \%)$ \\
\hline $70-79$ & & $2(4 \%)$ & $2(4 \%)$ \\
\hline \multicolumn{6}{|l|}{ Table 1. Age Related Prevalence of Thyroid Lesions } \\
\hline
\end{tabular}

\begin{tabular}{|l|c|c|}
\hline Cases & Total No. & $\begin{array}{c}\text { Lymphocytic } \\
\text { Thyroiditis (\%) }\end{array}$ \\
\hline Papillary carcinoma & 51 & $29(56)$ \\
\hline Follicular neoplasm & 48 & $21(44)$ \\
\hline Multinodular goitre & 100 & $39(39)$ \\
\hline \multicolumn{2}{|c|}{ Table 2. Lymphocytic Thyroiditis in various Thyroid } \\
Lesions
\end{tabular}

$\mathrm{p}=.1117$
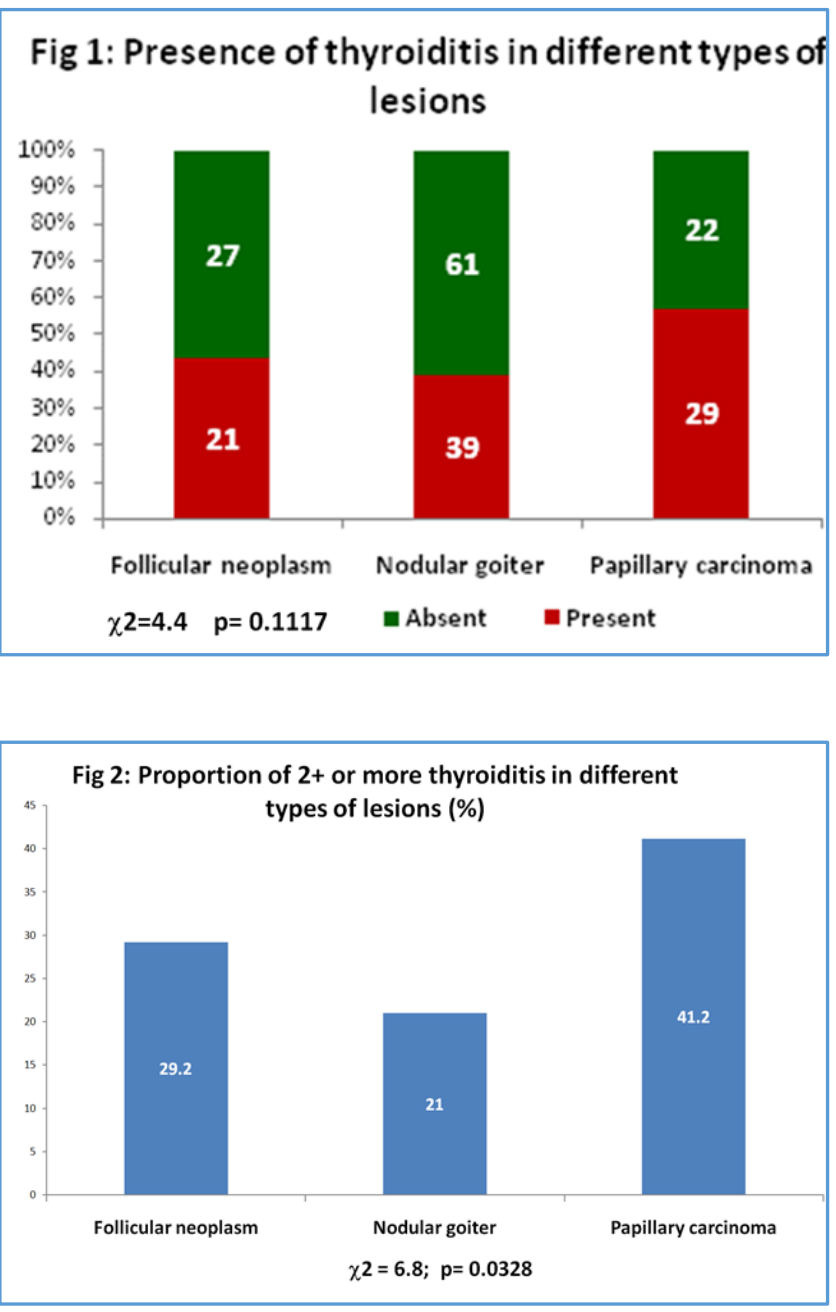

Higher grades of lymphocytic thyroiditis showing statistically significant association with papillary carcinoma thyroid.

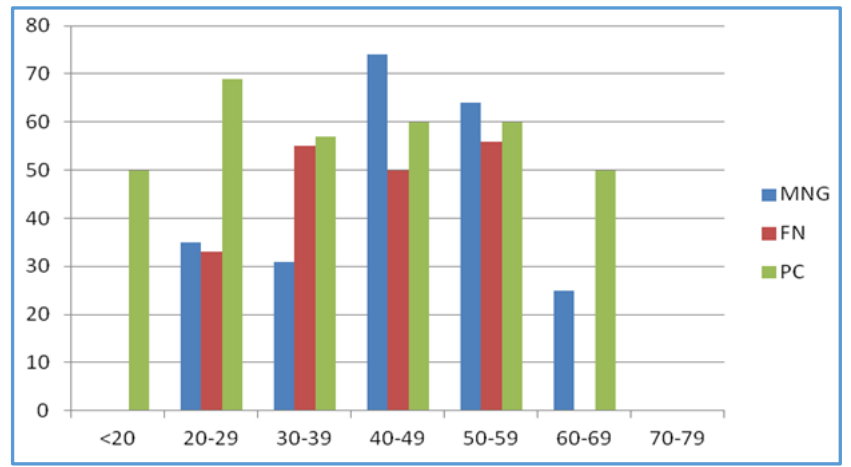

Figure 3. Age Related prevalance of Thyroiditis

\begin{tabular}{|c|c|c|c|c|c|}
\hline \multirow{2}{*}{ Type } & \multicolumn{5}{|c|}{ Grade } \\
\cline { 2 - 6 } & $\mathbf{0}$ & $\mathbf{1}$ & $\mathbf{2}$ & $\mathbf{3}$ & $\mathbf{4}$ \\
\hline $\begin{array}{c}\text { Follicular } \\
\text { Neoplasm }\end{array}$ & $\begin{array}{c}27 \\
(56.3)\end{array}$ & $\begin{array}{c}7 \\
(14.6)\end{array}$ & $\begin{array}{c}8 \\
(16.7)\end{array}$ & $\begin{array}{c}6 \\
(12.5)\end{array}$ & $0(0)$ \\
\hline $\begin{array}{c}\text { Multinodular } \\
\text { Goitre }\end{array}$ & $61(61)$ & $\begin{array}{c}18 \\
(18)\end{array}$ & $16(16)$ & $2(2)$ & $3(3)$ \\
\hline $\begin{array}{c}\text { Papillary } \\
\text { Carcinoma }\end{array}$ & $\begin{array}{c}22 \\
(43.1)\end{array}$ & $\begin{array}{c}8 \\
(15.7)\end{array}$ & $\begin{array}{c}10 \\
(19.6)\end{array}$ & $\begin{array}{c}8 \\
(15.7)\end{array}$ & $3(5.9)$ \\
\hline
\end{tabular}

Table 3. Distribution according to Grade of Thyroiditis in the different Types of Lesions [Number (\%)]

\begin{tabular}{|c|c|c|c|c|c|}
\hline \multirow{2}{*}{ Type } & \multicolumn{5}{|c|}{ Grade } \\
\cline { 2 - 6 } & $\mathbf{0}$ & $\mathbf{1}$ & $\mathbf{2}$ & $\mathbf{3}$ & $\mathbf{4}$ \\
\hline $\begin{array}{c}\text { Papillary } \\
\text { Carcinoma } \\
\text { (Near the } \\
\text { Tumour) }\end{array}$ & $\begin{array}{c}15 \\
(29 \%)\end{array}$ & $\begin{array}{c}16 \\
(31 \%)\end{array}$ & $\begin{array}{c}8 \\
(29 \%)\end{array}$ & $\begin{array}{c}7 \\
(29 \%)\end{array}$ & $\begin{array}{c}5 \\
(29 \%)\end{array}$ \\
\hline $\begin{array}{c}\text { Papillary } \\
\text { Carcinoma } \\
\text { (Rest of the } \\
\text { Thyroid) }\end{array}$ & 22 & 8 & 10 & 8 & 3 \\
\hline (43.1\%) & $(15.7 \%)$ & $(19.6 \%)$ & $(15.7 \%)$ & $(5.9 \%)$ \\
\hline
\end{tabular}

Table 4. Distribution according to Grade of Thyroiditis in Papillary Carcinoma near the Tumour and Rest of Thyroid

\begin{tabular}{|c|c|c|}
\hline & $\begin{array}{c}\text { Without } \\
\text { Lymphocytic } \\
\text { Thyroiditis }\end{array}$ & $\begin{array}{c}\text { With } \\
\text { Lymphocytic } \\
\text { Thyroiditis }\end{array}$ \\
\hline $\begin{array}{c}\text { Papillary } \\
\text { Carcinoma } \\
\text { (Near Tumour) }\end{array}$ & 15 & 36 \\
\hline $\begin{array}{c}\text { Papillary } \\
\text { Carcinoma (Rest of } \\
\text { the Thyroid) }\end{array}$ & 22 & 29 \\
\hline \multicolumn{2}{|c|}{ Table 5 } \\
\hline
\end{tabular}




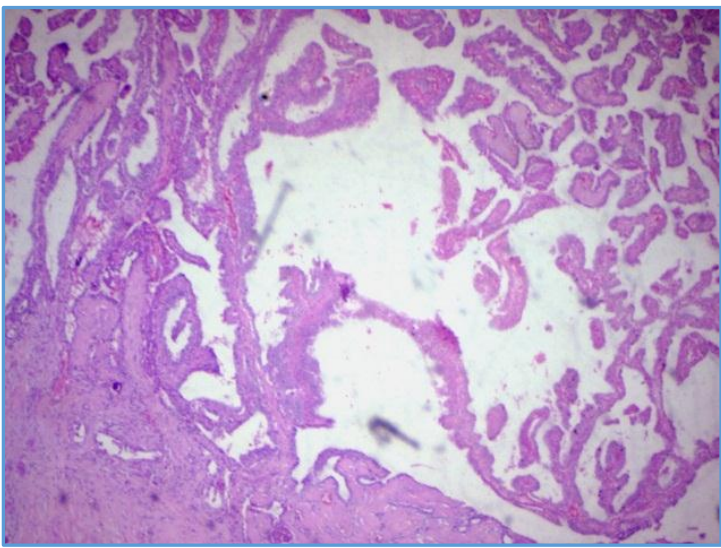

Figure 1. Papillary Carcinoma Thyroid



Figure 2. Papillary Carcinoma with Lymphocytic Thyroiditis



Figure 3. Lymphocytic Thyroiditis with Follicle Formation

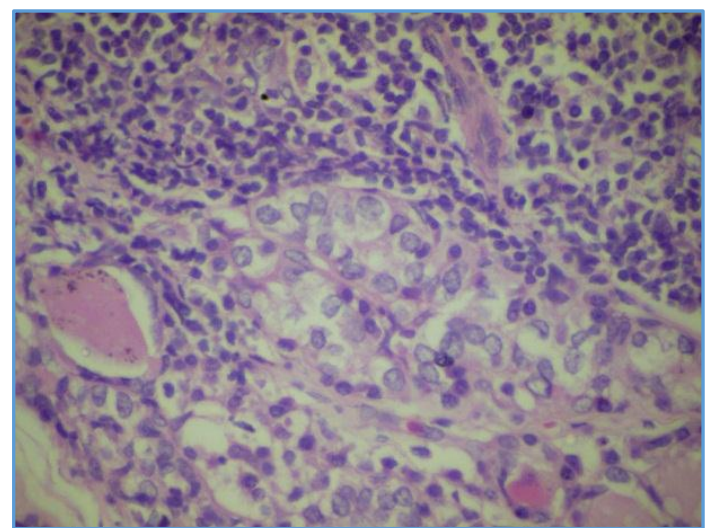

Figure 4. Lymphocytic Thyroiditis in Papillary Carcinoma Thyroid

\section{DISCUSSION}

A functional relationship between chronic inflammation and cancer was first proposed by Virchow in 1863 and has been sustained by clinical and epidemiological evidence. ${ }^{17}$ In a number of human malignancies, the presence of lymphocytic infiltration in or around a tumour is commonly viewed as representing a host tumour immune responses.18,19 The impact of this inflammatory response on tumour behaviour may be variable. For example, lymphocytic infiltration in hepatocellular carcinoma, ${ }^{20,21}$ melanoma, ${ }^{21}$ non-small-cell lung carcinoma ${ }^{22}$ and transitional cell carcinoma of the bladder ${ }^{23}$ have been reported to be associated with a better prognosis. The presence of tumour associated lymphocytes in patients with renal cell carcinoma ${ }^{24}$ and breast cancer ${ }^{25}$ are associated with more aggressive tumour behaviour.

Co-occurrences of chronic lymphocytic thyroiditis and thyroid gland cancer have been repeatedly reported.26,27 The aetiologic relationship between thyroid carcinoma and lymphocytic thyroiditis still remains a point of dispute, because it is not clear whether thyroiditis is induced secondarily by neoplasm ${ }^{20,21}$ or that thyroiditis predisposes the patient to the development of thyroid carcinoma. ${ }^{27}$ The potential protective effect of chronic lymphocytic thyroiditis in patients with papillary carcinoma thyroid is of interest and may-

1. Offer important information in the clinical management of patients with papillary carcinoma thyroid,

2. Improve the risk stratification of patients with the neoplasm, and

3. Lead to new immunotherapeutic approaches to treat patients with aggressive papillary carcinoma thyroid. 28,29

Present study included 100 cases of nodular colloid goitre, 52 cases of papillary carcinoma and 48 cases of follicular neoplasms (follicular adenoma and follicular carcinoma). In one papillary carcinoma, whole of thyroid was involved by neoplasm. All thyroid lesions are common in the age group of 20 to 50. Papillary carcinoma is the commonest cause, for which thyroidectomy is done below 20 yrs. After 70 yrs., thyroidectomies are usually done for neoplasm. No increase in cancer prevalence was found in this group as age increases. Out of the 52 cases of papillary carcinoma, 10 were males. Out of 48 follicular neoplasms, 9 cases were males.

Chronic autoimmune thyroiditis is common, but the prevalence reported in studies varies. The prevalence of chronic autoimmune thyroiditis is highest in countries with the highest intake of iodine, such as the United States and Japan. ${ }^{30,8}$ Forty to 45 percent of women and 20 percent of men in the United Kingdom and the United States have some degree of focal thyroiditis at autopsy ( 1 to 10 foci per square centimetre). When more severe thyroiditis (more than 40 foci per square centimetre) is considered, the prevalence declines to 5 to 15 percent in women and 1 to 5 percent in men.7,31

In the present study of the total 199 patients studied, 89 cases showed some degree of lymphocytic infiltration (44.7\%). The overall prevalence of chronic thyroiditis was significantly higher in patients with papillary carcinoma $(57 \%)$ than in that of multinodular goitre $(39 \%)$ or follicular neoplasm (21\%).

Comparison of our results with a similar studies performed in populations of Japanese, and White and African Americans ${ }^{32}$ is given below. 


\begin{tabular}{|c|c|c|c|}
\hline Population & $\begin{array}{c}\text { Adenomatous } \\
\text { Goitre \% }\end{array}$ & $\begin{array}{c}\text { Follicular } \\
\text { Neoplasm \% }\end{array}$ & $\begin{array}{c}\text { Papillary } \\
\text { Carcinoma \% }\end{array}$ \\
\hline Japanese & 30.2 & 32.8 & 63 \\
\hline $\begin{array}{c}\text { White } \\
\text { Americans }\end{array}$ & 50.0 & 51.3 & 76 \\
\hline $\begin{array}{c}\text { African } \\
\text { American }\end{array}$ & 17.1 & - & 46.2 \\
\hline Present Study & 39.0 & 44.0 & 56.0 \\
\hline \multicolumn{2}{|c|}{$\begin{array}{r}\text { Table 6. The Overall Prevalence of Thyroiditis in } \\
\text { Thyroidectomy Specimens in various Populations }\end{array}$} \\
\hline
\end{tabular}

A higher prevalence and severity of thyroiditis in patients with papillary carcinoma compared with that of patients with multinodular goitre or follicular adenoma was evident among all three races. Furthermore, a high coexistence of thyroiditis and papillary carcinoma was observed in Japanese girls aged 10 to 19 years. ${ }^{32}$ No age-related increase was noted after the third decade. In our series, there is an age-related increase in the prevalence of thyroiditis from 10 to $30 \mathrm{yrs}$. In 10 - $20 \mathrm{yrs}$. the prevalence is $50 \%$ and 20 - 30 yrs. it is increased to $70 \%$ and no age-related increase is noted after the third decade. The difference of the prevalence of moderate-to-severe thyroiditis (Grade 2 to 4 ) also is significant ( $p<0.0328$ ) between patients with papillary carcinoma and adenomatous goitre or follicular neoplasms. The comparison of the prevalence of chronic thyroiditis among these three kinds of thyroid diseases indicates a real association between thyroiditis and papillary carcinoma.

Like many other tumours, papillary carcinoma also show some degree of lymphocytic infiltration. Whether it is a part of chronic lymphocytic thyroiditis or it is an immune response of the host towards the tumour is not very clear. In cases of papillary carcinoma, lymphocytic infiltration was graded within $2 \mathrm{~cm}$ of the tumour and compared with that of the rest of the non-tumourous area of the thyroid, more severe lymphocytic infiltration (Grade 2 or more) within the tumour than in the non-tumourous thyroid tissue was observed in relatively few cases. Accordingly, it seems likely that the lymphocytic and filtration into the thyroid tumour occurred secondarily to chronic thyroiditis, because the severity of lymphocyte infiltration was lower within the tumour than in the non-tumourous thyroid tissue in the majority of patients. These findings appear to contradict the former reports suggesting that lymphocyte infiltration in the non-tumourous thyroid tissue was induced through an immune mechanism by the neoplasm. ${ }^{1}$

\section{CONCLUSION}

Papillary carcinoma shows association with lymphocytic thyroiditis. Lymphocytic thyroiditis was more in papillary carcinoma when compared to follicular neoplasm and nodular goitre. Lymphocytic thyroiditis associated with papillary carcinoma is most probably not an immune reaction against tumour antigen.

Recommendations- Moderate-to-higher grades of lymphocytic thyroiditis shows association with papillary carcinoma thyroid, hence patients with lymphocytic thyroiditis should be followed up.

\section{REFERENCES}

[1] Segal K, Ben-Bassat M, Avraham A, et al. Hashimoto's thyroiditis and carcinoma of the thyroid gland. Int Surg 1985;70(3):205-9.

[2] Kashima K, Yokoyama S, Noguchi S, et al. Chronic thyroiditis as a favorable prognostic factor in papillary thyroid carcinoma. Thyroid 1998;8(3):197-202.

[3] Mazokopakis EE, Tzortzinis AA, Dalieraki-Ott EI, et al. Coexistence of Hashimoto's thyroiditis with papillary thyroid carcinoma. A retrospective study. Hormones (Athens) 2010;9(4):312-7.

[4] Busó MN, Perdigó MS, Bielsa IR, et al. Dedifferentiated thyroid carcinoma in children a study of 80 cases. Med Clin (Barc). Epub 2009;133(9):339-43.

[5] Werner SC. Ingbar's The Thyroid: a fundamental and clinical text. $8^{\text {th }}$ edn. Philadelphia, JB Lippincott-Raven, 1996.

[6] Jaksic J, Dumic M, Filipovic B, et al. Thyroid diseases in a school population with thyromegaly. Arch Dis Child 1994;70(2):103-6.

[7] Marwaha RK, Tandon N, Karak AK, et al. Hashimoto's thyroiditis: countrywide screening of goitrous healthy young girls in postiodization phase in India. J Clin Endocrinol Metab 2000;85(10):3798-802.

[8] Laurberg P, Pedersen BI, Knudsen N, et al. Environmental iodine intake affects the type of nonmalignant thyroid disease. Thyroid 2001;11(5):457-69.

[9] Sehestedt T, Knudsen N, Perrild H, et al. Iodine intake and incidence of thyroid cancer in Denmark. Clin Endocrinol (Oxf) 2006;65(2):229-33.

[10] Dayan CM, Daniels GH. Chronic autoimmune thyroiditis. N Engl J Med 1996;335(2):99-107.

[11] Vanderpump MP. The epidemiology of thyroid diseases. Br Med Bull 2011;99(1):39-51.

[12] Tunbridge WM, Evered DC, Hall R, et al. The spectrum of thyroid disease in a community: the Whickham survey. Clin Endocrinol (Oxf) 1977;7(6):481-93.

[13] Wang C, Crapo LM. The epidemiology of thyroid disease and implications for screening. Endocrinol Metab Clin North Am 1997;26(1):189-218.

[14] Harach HR, Escalante DA, Onativia A, et al. Thyroid carcinoma and thyroiditis in an endemic goiter region before and after iodine prophylaxis. Acta Endocrinol (Copenh) 1985;108(1):55-60.

[15] Kapila K, Sathar SA, Al-Rabah NA, et al. Chronic lymphocytic (Hashimoto's) thyroiditis in Kuwait diagnosed by fine needle aspirates. Ann Saudi Med 1995;15(4):363-6.

[16] Jackson IMD. Thyroiditis in KL Becker (eds). Principles and practice of endocrinology and metabolism. $1^{\text {st }}$ edn. Philadelphia: JB Lippincott and Co; 1990:370-6.

[17] Balkwill F, Mantovani A. Inflammation and cancer: back to Virchow? Lancet 2001;357(9255):539-45.

[18] Shu S, Plautz GE, Krauss JC, et al. Tumor immunology. JAMA 1997;278:1972-81.

[19] Herberman RB. Cellular immunity. In: The molecular basis of cancer. Mendelson J, Howley PM, Israel MA, et al. (eds). Philadelphia: Saunders, 1995.

[20] Kawata A, Une Y, Hoskawa M, et al. Tumor infiltrating lymphocytes and prognosis of hepatocellular carcinoma. Jpn J Clin Oncol 1992;22(4):256-63. 
[21] Halpern AC, Schuchter LM. Prognostic models in melanoma. Semin Oncol 1997;24(1 Suppl 4):S2-7.

[22] Lipford EH, Sears DL, Eggleston JC, et al. Prognostic factors in surgically resected limited-stage, nonsmall cell carcinoma of the lung. Am J Surg Pathol 1984;8(5):357-65.

[23] Lipponen PK, Eskelinen MJ, Jauhiainen K, et al. Tumour infiltrating lymphocytes as an independent prognostic factor in transitional cell bladder cancer. Eur J Cancer 1992;29A(1):69-75.

[24] Kolbeck PC, Kaveggia FF, Johansson SL, et al. The relationship among tumour-infiltrating lymphocytes, histopathologic findings, and long-term clinical followup in renal cell carcinoma. Mod Pathol 1992;5(4):4205.

[25] Aaltomaa S, Lipponen $\mathrm{P}$, Eskelinen $\mathrm{M}$, et al. Lymphocytic infiltrate as a prognostic variable in female breast cancer. Eur J Cancer 1992;28A(45):859-64.

[26] Crile G, Fisher ER. Simultaneous occurrence of thyroiditis and papillary carcinoma; report of two cases. Cancer 1953;6(1):57-62.
[27] Kamma H, Fujii K, Ogata T. Lymphocytic infiltration in juvenile thyroid carcinoma. Cancer 1988;62(9):198893.

[28] Baker JR. The immune response to papillary thyroid cancer. J Clin Endocrinol Metab 1995;80(12):3419-20.

[29] Boyd CM, Baker JR. The immunology of thyroid cancer. Endocrinol Metab Clin North Am 1996;25(1):159-79.

[30] Matsubayashi S, Kawai K, Matsumoto Y, et al. The correlation between papillary thyroid carcinoma and lymphocytic infiltration in the thyroid gland. J Clin Endocrinol Metab 1995;80(12):3421-4.

[31] Williams ED, Doniach I. The post-mortem incidence of focal thyroiditis. J Pathol Bacteriol 1962;83:255-64.

[32] Okayasu I, Fujiwara M, Hara Y, et al. Association of chronic lymphocytic thyroiditis and thyroid papillary carcinoma. A study of surgical cases among Japanese whites and African Americans. Cancer 1995;76(11):2312-8. 